\title{
Analysis of Sources of Fruit Wastages in Retail outlets in Chennai, Tamilnadu, India
}

\author{
R. Arivazhagan, P. Geetha, and Ravilochanan Parthasarathy
}

\begin{abstract}
India is the second largest producer of overall fruits. India produces over 46 million tonnes of fruits accounting for around $10 \%$ of the world's production. In spite of being a major producer of fruits, nearly $72 \%$ of fruits are wasted in India due to poor facility or absence of storage, logistics and processing support. With a high percentage of waste of fruits, the value loss could be imagined. Minimizing wastage at the processing level has been studied by the same researcher in his previous study. Now the researcher extended this study to identify the sources and minimize the wastages in both organized and un-organized fruits and vegetable retail markets. Moreover, retail outlets of fruits and vegetables are more dependent on cold storage, logistics and distribution, this study includes the same to identify the source of wastages. Analysis of sources of wastage of fruits in retail markets and cold storage is undertaken to suggest ways out to minimize this loss and improve the return for both agriculture and retail vendors. This study also helps to minimize the cost of fruits and vegetables so that consumer too gets benefitted. This research is confined to both organized and un-organized retail outlets and their distribution systems and cold storage units in Tamilnadu, a leading producer of fruits and vegetables in India.
\end{abstract}

Index Terms-Agriculture, fruits and vegetables, retail, Wastages.

\section{INTRODUCTION}

India ranks first in the world with an annual output of 32 MT fruits, about $8 \%$ of the world's fruit production; also is the second largest producer of vegetables (ranks next to China) and accounts for about $15 \%$ of the world's production of vegetables. The current production level is over 71 million MT [1]. But the real challenge starts after the production. More than 72 percent of the vegetable and fruits are wasted in every year in the absence of proper retailing, storage and other infrastructure facilities [2]. The sector is constrained by widespread fragmentation in the supply chain, low productivity levels, and huge post harvest losses arising out of inadequate storage, cold chain and transport infrastructure, logistics and supply chain management. Only organized and traditional retailing will ultimately drive the growth of the fruits and vegetable sector in the country.

Manuscript received April 10, 2012; revised May 9, 2012.

R. Arivazhagan and R. Parthasarathy are with School of Management, SRM University, Kattankulathur (email: ravilochanan@gmail.com).

P. Geetha Assistant Professor, Dept. of Food Process Engineering, SRM University, Kattankulathur.

\section{PROBLEM FocUS}

With a high percentage of waste of fruits and vegetable, the value loss could be imagined. Moreover, India is facing food security as the biggest problem in terms of several factors which includes malnourishment is one of the factors, though India is the second largest producer of nutritional rich commodities such as fruits and vegetables. Wastages happening in different stages till its consumption. Wastages in processing stage is already been done by the same researcher [3]. Hence this study is focusing to find out sources of wastages in retail outlets in order to minimize the fruits and vegetable wastages so as to we could increase the income of both farmers and retail vendors. In addition to that we could minimize the malnourishment at some extent.

\section{OBJECTIVES}

- To identify the sources of wastages of fruits and vegetables in both organized and unorganized retail outlets in Chennai.

- To prioritize the sources of wastages and analyze the major reasons of fruits and vegetables wastages.

- To quantify the money value of fruits and vegetables wastages.

\section{REVIEW Of LITERATURE}

Dave D. Weatherspoon, James F. Oehmke, Marcus Coleman, Lorraine Weatherspoon, addresses the knowledge gap concerning the demand for fruits and vegetables in a predominantly African American food desert. Using retail data from a non-profit owned retail outlet specializing in fresh fruits and vegetables in the Piety Hill community of Detroit, this study estimates the income and price elasticities of fresh fruits and vegetables among residents of this lowincome, food-desert community [4].

M. Fehr and D.C. Romão conducted study on modeling the success of fruit and vegetable marketing. This study develops a scoring guide that can assist commercial establishments and households in evaluating and mitigating the loss potential for fruit and vegetables within their operations. The scoring model separately addresses losses related to products and losses related to establishments [5].

Katinka Weinberger, Christian Genova II, Antonio Acedo studied Quantifying postharvest loss in fruits and vegetables along the supply chain in Vietnam, Cambodia and Laos. This study finds that the average loss of the selected vegetables is about $17 \%$, and that farmers are the most 
vulnerable group compared to middlemen and retailers who both have more control on product prices. It recommends developing measures to contain disease problems for farmers, and improving marketing efficiency through standardization of product quality for middlemen and retailers. This study investigates the volume and value of vegetable losses upstream along the supply chain, and identifies the main reasons and the preventive measures undertaken at each stage in the supply chain to abate postharvest losses [6].

Rory C. Flemmer and Claire L. Flemmer was made study on Innovations in fruit packing for both kiwi fruit and apples. They were discovered two innovative packing methods. Firstly, a novel packing line for kiwifruit and secondly, an automated apple packing system. Through which they were minimized wastage during packing and transportation [7].

A. Frank Bollen conducted a study on technological innovations in sensors for assessment of postharvest mechanical handling systems. There are two relationships combined to provide an estimate of the level of damage that can be expected from any handling event [8].

Veena A, K. Nagendra Babu and H.R. Venkatesha studied the supply chain in marketing fresh produce. As per the survey conducted for this study, important drawbacks of the current Supply Chain (SC) are number of intermediaries, high level of wastage, quality degradation, poor infrastructural facilities and high cost. Fresh produce market has immense influence on the socioeconomic and even political conditions. Close to $30 \%$ of the $\mathrm{F} \& \mathrm{~V}$ grown is going waste [9].

A study focusing on major issues that exist in the supply chain of fruits and vegetables include the losses during post harvest handling, processing, packaging and transportation was undertaken. The loss of fruits and vegetables during transportation is said to be in the range of $20-30 \%$ in countries like China and India. In many countries including China and India - two largest producers of fresh fruits and vegetables in the world - the existing cold storage facilities, reefer vehicles, product traceability solutions and other infrastructural facilities are insufficient to counter the problem of high supply chain losses [10].

Ministry of Food Processing Industry (MFPI), Government of India says that without a strong and dependable cold chain, a vital sector like F\&V processing industry, which is based mostly on perishable products, cannot survive and grow. Even at currents level of production, wastage in $\mathrm{F} \& \mathrm{~V}$ is estimated at $35 \%$, major reasons being inadequate storage, transportation, cold chain facilities and other infrastructure support facilities [11].

The Hindu dated, Jun 25, 2010, Friday stated that Around 5 to 10 per cent of vegetables and fruits that arrive at the Koyambedu wholesale market in the city are wasted daily for want of proper temperature-controlled storage facilities, according to the traders [12].

India has revolutionized its agriculture but there is the phenomenon of Food Mountains and lakes alongside poverty, malnutrition and ill-health. For an emerging economy of India food insecurity is both an immediate tragedy and a threat to long-term well-being. While we expect 'more' from agriculture we also need to accept the fact that agriculture by itself is unlikely to be able to eradicate hunger completely. Alternative strategies need to be (re)searched and adopted, quickly and safely. Agriprenuers and all connected with the food, nutrition and heath sectors are vital actors in the field game [13].

\section{RESEARCH METHODOLOGY}

This research has been conducted based on descriptive in nature. Since Koyambedu (which is located in Chennai) is one of the largest fruits and vegetable market in the Asia, it can supply all varieties of fruits and vegetables to the retailers who are in Chennai. Hence Chennai has been chosen for our market survey. Data have been collected through schedule. Questionnaire has been prepared after detailed discussion with some of local retailers. Then researcher identified five numbers of two member teams and then trained them based on research requirements. All five teams conducted interview with 65 numbers of both organized and unorganized retailers those who are in Chennai. Based on the respondents' response, collected data has been coded and tabulated which is considered as master table for analysis. All these data were transferred to analytical software called SPSS. Through SPSS, researcher has performed frequency of variable, regression, weighted average and factor analysis calculations.

\section{DATA ANALYSIS}

\section{A. Frequency Analysis}

Following frequency table indicates the variables which have more than $70 \%$ response level.

TABLE I: FREQUENCY ANALYSIS WITH MORE THAN 70\% RESPONSE LEVEL

\begin{tabular}{|c|c|c|c|}
\hline SI. No & Variable & $\begin{array}{c}\text { Variable } \\
\text { response }\end{array}$ & $\begin{array}{c}\text { Response } \\
\text { level }\end{array}$ \\
\hline 1 & Nature of retail format & Unorganized & $88 \%$ \\
\hline 2 & Purchase place & Koyambedu & $92 \%$ \\
\hline 3 & Transport system & Rented & $77 \%$ \\
\hline 4 & Type of packing & Gunny bags & $78 \%$ \\
\hline 5 & $\begin{array}{c}\text { Number of distribution } \\
\text { channels }\end{array}$ & $3-5$ channels & $71 \%$ \\
\hline 6 & $\begin{array}{c}\text { Cold storage } \\
\text { utilization }\end{array}$ & No & $99 \%$ \\
\hline 7 & Wastage disposal & Garbage & $74 \%$ \\
\hline
\end{tabular}

Since other variables are having different response levels, researcher would like to indicate them in overall manner. Around $51 \%$ of retailers are purchasing whether daily or alternative days. $43 \%$ of retailers are purchasing 2 to 3 times in a week. Most of the retailers are purchasing between 100 $\mathrm{Kg}$ to $500 \mathrm{Kg}$ per day. Around $57 \%$ of retailers preferred both quality and price during commodity purchase and $31 \%$ of retailers are considered only quality rather than price during purchase. Handling wastage is not more than $15 \%$ at any outlets in Chennai. Similarly, wastage during transportation is also not more than $15 \%$ except one respondent. Wastage due to poor packing is also not more than $15 \%$. Whereas, wastage due to poor quality is falls between $6 \%$ and $25 \%$ except 4 retailers. Similarly, unsold waste is also falls between $6 \%$ and $25 \%$ except 3 retailers. Altogether overall wastage is falls between $11 \%$ and $40 \%$. 
$54 \%$ of retailers are not taking any precaution methods to increase their commodity life and maintain freshness. $23 \%$ retailers are following their own techniques to preserve their commodities.

\section{B. Factor Analysis}

Factor analysis has utilized for determining major wastage resources. Based on the total variance explained, it is confirmed that, there are six components influencing the major wastage with $69 \%$ since their total loading is more than one. Since from 7 to $17^{\text {th }}$ components are having total Eigen values less than one, they have not included in this table.

TABLE II: FACTOR ANALYSIS - TOTAL VARIANCE EXPLAINED

\begin{tabular}{|c|c|c|c|c|c|c|c|c|c|}
\hline \multirow{2}{*}{$\begin{array}{c}\text { Co } \\
\text { mp } \\
\text { one } \\
\text { nt }\end{array}$} & \multicolumn{3}{|c|}{ Initial Eigen values } & \multicolumn{3}{|c|}{$\begin{array}{l}\text { Extraction Sums of } \\
\text { Squared Loadings }\end{array}$} & \multicolumn{3}{|c|}{$\begin{array}{l}\text { Rotation Sums of } \\
\text { Squared Loadings }\end{array}$} \\
\hline & Total & $\begin{array}{c}\% \text { of } \\
\text { Varian } \\
\text { ce }\end{array}$ & $\begin{array}{l}\text { Cumula } \\
\text { tive } \%\end{array}$ & Total & $\begin{array}{c}\% \text { of } \\
\text { Varian } \\
\text { ce }\end{array}$ & $\begin{array}{c}\text { Cumulativ } \\
\text { e } \%\end{array}$ & Total & $\begin{array}{c}\% \text { of } \\
\text { Varianc } \\
\mathrm{e}\end{array}$ & $\begin{array}{c}\text { Cumula } \\
\text { tive } \%\end{array}$ \\
\hline 1 & 3.732 & 21.950 & 21.950 & 3.732 & 21.950 & 21.950 & 2.815 & 16.560 & 16.560 \\
\hline 2 & 2.323 & 13.664 & 35.614 & 2.323 & 13.664 & 35.614 & 2.809 & 16.525 & 33.085 \\
\hline 3 & 1.702 & 10.014 & 45.629 & 1.702 & 10.014 & 45.629 & 1.697 & 9.983 & 43.068 \\
\hline 4 & 1.581 & 9.299 & 54.927 & 1.581 & 9.299 & 54.927 & 1.598 & 9.400 & 52.468 \\
\hline 5 & 1.261 & 7.419 & 62.346 & 1.261 & 7.419 & 62.346 & 1.543 & 9.074 & 61.542 \\
\hline 6 & 1.149 & 6.756 & 69.102 & 1.149 & 6.756 & 69.102 & 1.285 & 7.561 & 69.102 \\
\hline
\end{tabular}

TABLE III: FACTOR ANALYSIS - ROTATED COMPONENT MATRIX ${ }^{\mathrm{A}}$

\begin{tabular}{|c|c|c|c|c|c|c|}
\hline \multirow{2}{*}{ Factors } & \multicolumn{6}{|c|}{ Components } \\
\hline & 1 & 2 & 3 & 4 & 5 & 6 \\
\hline Nature of business & .813 & -.022 & .084 & .128 & -.081 & -.098 \\
\hline Experience in the business & -.052 & .014 & .868 & .073 & .000 & -.060 \\
\hline Purchase place & -.011 & -.022 & .031 & .088 & .098 & .739 \\
\hline Purchase frequency & .127 & -.016 & .140 & .768 & .218 & .301 \\
\hline Quantity in single purchase & -.520 & -.111 & .499 & .436 & -.222 & .014 \\
\hline Mode of transportation & .781 & .029 & -.114 & .136 & .233 & .056 \\
\hline Purchase factors & .415 & .120 & -.002 & .573 & .014 & -.205 \\
\hline $\begin{array}{l}\text { Type of Packing during } \\
\text { transport }\end{array}$ & -.215 & -.176 & -.328 & .255 & .719 & -.027 \\
\hline Handling wastage & -.020 & .502 & -.477 & .094 & .194 & -.330 \\
\hline Wastage during transportation & .299 & .281 & .080 & $\begin{array}{c}- \\
.001\end{array}$ & .699 & .058 \\
\hline $\begin{array}{l}\text { Wastage due to poor packing } \\
\text { methods }\end{array}$ & .209 & .823 & .060 &. & .025 & -.015 \\
\hline Wastage due to poor quality & -.194 & .658 & -.161 & .376 & -.286 & -.163 \\
\hline Unsold wastage & .174 & .543 & -.351 & .451 & -.015 & .187 \\
\hline Overall wastage & -.052 & .859 & .013 & .032 & .092 & .080 \\
\hline $\begin{array}{l}\text { Number of distribution } \\
\text { channels from farmer to } \\
\text { retailer }\end{array}$ & .563 & .489 & -.007 & .011 & .066 & .352 \\
\hline Cold storage utilization & .586 & .084 & -.304 & .129 & -.395 & -.188 \\
\hline
\end{tabular}

Hence, based on rotation matrix, we could find the different factors which influencing more wastage by fixing cut-off values as 0.5 and above. Out of these six components, first component contains four factors with heavy loading such as nature of business, method of transportation, number of distribution channels from farmer to retailer and Cold storage utilization. Second component contains five factors with heavy loading such as handling wastage, wastage due to poor packing methods, wastage due to poor quality, unsold wastage and overall wastage. Third component contains two factors with heavy loading viz. experience in the business and quantity in single purchase.
Fourth component contains two factors with heavy loading which are purchase frequency and purchase factors. Fifth component contains two factors with heavy loading such as type of packing during transportation and wastage during transportation. Finally, sixth component contains one factor with heavy loading which is purchase place.

\section{Weighted Average Analysis}

Weighted average of overall wastage has been calculated to find out total value loss. It has been calculated by considering percentage value as weights and mid value of wastage range as average wastage. Through this researcher has found $23 \%$ of fruits and vegetable wastage is happening in retail outlets.

TABLE IV: WEIGHTED AVERAGE OF OVERALL WASTAGE

\begin{tabular}{|c|c|c|c|c|}
\hline $\begin{array}{c}\text { Wastage } \\
\text { range }\end{array}$ & Frequency & Percent & $\begin{array}{c}\text { Average } \\
\text { wastage }\end{array}$ & Weighted Average \\
\hline $0-10 \%$ & 2 & 3.1 & $5 \%$ & \multirow{5}{*}{ 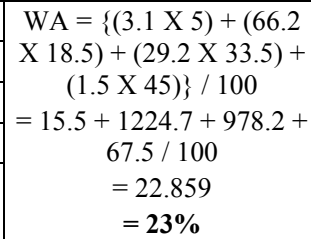 } \\
\hline $11-25 \%$ & 43 & 66.2 & $18.5 \%$ & \\
\hline $26-40 \%$ & 19 & 29.2 & $33.5 \%$ & \\
\hline$>40 \%$ & 1 & 1.5 & $45 \%$ & \\
\hline Total & 65 & 100.0 & & \\
\hline
\end{tabular}

\section{Regression Analysis}

Multiple regression was fitted to identify the determinants of overall wastage. The regression was fitted with overall wastages as the dependent variable and Wastage during transportation, Wastage due to poor packing methods, Wastage due to poor quality and unsold wastages are as independent variables. The equation fitted, an $R^{2}$ value $\left(R^{2}\right.$ $=0.461)$ indicated that the independent factors included for the analysis. The $F$ value $(F=12.829)$ implied that $R^{2}$ is statistically significant and so the equation is fit for interpretation. From the equation we could notice that wastage due to poor packing methods influencing more wastage. For every unit increase in the poor packing method the wastage would go up by 0.500 units. Similarly wastage will also influenced by poor quality of fruits and vegetables. For every unit increase of poor quality, wastage will increase by 0.249 units. Except these two factors all other factors are non-significant.

TABLE V: COEFFICIENTS OF REGRESSION ANALYSIS

\begin{tabular}{|c|c|c|c|c|c|}
\hline \multirow[t]{2}{*}{ Model } & \multicolumn{2}{|c|}{$\begin{array}{c}\text { Unstandardized } \\
\text { Coefficients }\end{array}$} & \multirow{2}{*}{$\begin{array}{c}\begin{array}{c}\text { Standardized } \\
\text { Coefficients }\end{array} \\
\text { Beta } \\
\end{array}$} & \multirow[t]{2}{*}{$\mathbf{t}$} & \multirow[t]{2}{*}{ Sig. } \\
\hline & B & Std. Error & & & \\
\hline (Constant) & .645 & .282 & & 2.292 & .025 \\
\hline $\begin{array}{l}\text { Wastage during } \\
\text { transportation }\end{array}$ & .135 & .107 & .128 & 1.257 & .213 \\
\hline $\begin{array}{l}\text { Wastage due to } \\
\text { poor packing } \\
\text { methods }\end{array}$ & .500 & .123 & .457 & 4.066 & .000 \\
\hline $\begin{array}{l}\text { Wastage due to } \\
\text { poor quality }\end{array}$ & .249 & .109 & .266 & 2.287 & .026 \\
\hline Unsold wastage & .051 & .113 & .051 & .455 & .651 \\
\hline
\end{tabular}

\section{RESUlTS AND DisCUSSIONS}

Frequency analysis shows that, only $12 \%$ organized retail in the total sample. It is intentionally taken since India is having around $8 \%$ organized retail ${ }^{14}$. Reliance fresh is the 
one and only retailer purchasing directly from farmers. Very few retailers are purchasing just green leaves alone from the farmers, all other vegetables from the Koyambedu market. Remaining $92 \%$ of the total retailers are purchasing their goods from Koyambedu market. This itself put platform for price increase of fruits and vegetables due to increase of distribution channels and transport distance and costs.

$$
\text { Equation is that, } \quad \mathrm{Y}_{\mathrm{ow}}=0.645+0.135^{\mathrm{ns}} \mathrm{WDT}+0.500{ }^{\mathrm{s}} \mathrm{WDPP}+0.249^{\mathrm{s}} \mathrm{WDPQ}+0.051{ }^{\mathrm{ns}} \mathrm{USW}
$$

$$
\text { Where, ns - Non significant and } \quad(1.257) \quad(4.066)
$$

Around $51 \%$ of retailers are purchasing daily or alternative days and $43 \%$ of retailers are purchasing 2 to 3 time in a week. During interview with retailers, researcher came to know that there is no planning for purchase. Simply they are purchasing whenever their stock comes to an end. Due to lack of planning, some time, retailers are facing problem of transport availability, goods availability, price fluctuations. Hence automatically price is getting increased.

Around $77 \%$ of the people are using rented system of transport. This itself affect the price of fruits and vegetable and profit of retailers. Though, initial cost of vehicle is high, it would play profit at long run. Moreover, it indirectly affects quality of the goods due to careless handling, packing and driving by third person. On other hand, own vehicle retailers are complaining that, rented is better due to increase of fuel and maintenance cost. But still retailers have to make this decision based on total quantity of purchase and sales, because high quantity of sales will yield good profit and own vehicle will provide better benefit for handling high quantity though fuel and maintenance cost is high.

$57 \%$ of retailers are considering both quality and price are the major factors for purchase and $31 \%$ of retailers are considered quality alone. Here, researcher revealed that very few retailers are maintaining good relationship with suppliers and transport people others are not bothering about the service and relationship. Hence, researcher believed that good service and relationship with supplier and transporters will reduce wastage through proper sorting, fixing right price for different quality of goods, careful handling etc.

Out of total number of retailers, $78 \%$ of retailers are using normal gunny bags or plastic bags for their packing of vegetables. Even, they are not using these bags for individual items. Instead, they are using these bags as common bag for all items. Hence, damage of vegetable is getting increase. This kind of packing leads damage during transportation too. These damages increase the wastages of vegetables. Most of the fruit vendors are using carton boxes as their packing method. Though they are using carton boxes, wastages are happening poor finishing of packing and careless handling. Vegetables are getting more damage than the fruits based on their type of packing.

Handling wastage is not more than $15 \%$ at any retail outlets in Chennai. $45 \%$ of retailers realizing 0 to $5 \%$ and remaining $55 \%$ retailers realizing 6 to $15 \%$ wastage due to poor handling. These kinds of damages are happening through both customer and vendor handling. Already researcher has discussed different situations of careless vendor handling. While selecting the goods, customers are testing quality of goods by breaking, pressing etc. Hence, damage automatically will get increase. Similarly, wastage during transportation is also not more than $15 \%$ except one respondent. One respondent has expressed more than 15\% wastage during transportation. Retailers are giving the reasons for these kinds of wastages that poor road conditions and poor packing systems. Wastage due to poor packing is also not more than $15 \%$. Reasons for these kinds of wastage have already been discussed in type of packing method. Wastage during transportation and wastage due to poor packing are integrated factors one depending other. Wastage due to poor quality is falls between $6 \%$ and $25 \%$ except 4 retailers. Other 4 retailers are realizing just 0 to $5 \%$ of wastages due to poor quality. Retailers are defining poor quality through goods affected by insects and rodents, scratches and cleft on the goods, un-matured and overmatured goods, beaten spots which directly decay, dark and decayed spots, artificial ripened fruits, etc. Similarly, unsold waste is also falls between $6 \%$ and $25 \%$ except 3 retailers. These 3 retailers are realizing just 0 to $5 \%$ wastage due to unsold. Retailers are justifying unsold wastage would happen due to poor quality goods, expiry of goods through decay, dark spots, spoilage of freshness, and refilling of stocks with new fresh stock etc. Altogether overall wastage is falls between $11 \%$ and $40 \%$. All the above wastage is not happening with all the retailers. Some type of wastages will happen in some retailers. Around $66 \%$ of retailers are realizing that 11 to $25 \%$ of wastages and around $29 \%$ of retailers are realizing that 26 to $40 \%$ of wastages. Researcher has calculated around $23 \%$ of wastage through weighted average. It means that, if retailers spend INR 1000 , then the same retailer will incur a loss of INR 230 just because of wastage alone.

$71 \%$ of retailers are using 3 to 5 numbers of distribution channels for getting their goods. Each distribution channels will have their own profit margin. Hence cost of goods automatically will get increase. Even report of eleventh five year plan of India is also stating that, price of fruits and vegetable is increasing 6 to 8 times before reaching the customer from the harvesting due to increased number of middle $\operatorname{man}^{15}$.

Major issue found out in this research is that, no retailers are utilizing cold storage except reliance fresh. Though cold storage is one of the important concepts for minimizing wastages of fruits and vegetables, it is very sad that no retailers are using cold storage for their commodities. Apart from this thing, it is very surprise that $18.5 \%$ of retailers don't know about what is cold storage. Reliance fresh is the one and only retail store using cold storage, which realizing the overall wastage is just $12 \%$ which is $11 \%$ less than the overall wastage of this research. Hence researcher feels that $50 \%$ of the total wastage can be easily reduced through cold storage itself.

Another surprising finding in this research is that, $74 \%$ of the retailers are simply disposing their wastage to garbage. 
Remaining retailers are disposing with useful manner such as manure, cattle feed etc. Hence, researcher suggested that, retailers can make money through proper disposal methods. Moreover, they can go for research and developments activities for recycling of fruits and vegetables so that retailers could minimize value loss from the wastages.

Around $54 \%$ of the retailers are not following any precaution methods for minimizing their fruits and vegetable wastages. Remaining retailers are following different strategies for minimizing their wastages. One of the important strategies is that, reducing price for end stock or discount sale or offer sale. This strategy is mostly followed by organized retailers. Moreover, organized retailers are taking other measures through refrigerators; air conditioned environments, proper handling methodologies, proper packing and transportation system etc. Un-organized retailers are following other different strategies like second sale to juice shops or any other processing shops, keeping goods in cool condition by sprinkling of water on the goods etc. One more interesting finding is that, more experienced retailers are doing correct forecasting and demand estimation without any tools or calculation, so that they are minimizing wastages.

Finally, they are facing some of the challenges and difficulties during their business. First and major challenge is that, price fluctuation. Other challenges are electricity problem, increase of cost of fuel, rent of transportation, rent of building or shop, poor road condition, etc. Hence, they are expecting to channelize the some issues. One of the important issues is that price fluctuation. Standardization of price through government or any private control bodies is the major requirement for most of the retailers. Moreover, retailers are expecting other support from government or association like common transport for supply of goods to cluster of retailers in one area with reduced or free of cost, rental and electricity subsidies, common cold storage for cluster of retailers in one area with reasonable or free of cost etc.

With these findings and discussion, researcher suggested that government can increase number of cold storages in cluster basis so that wastages can be minimized. Other choice is that, cluster of retailers can build common cold storage through forming retail cooperatives, that can be utilized for their own as well as they can rent space to others too. Similarly all other services such as direct purchase from farmers, proper packing, transport, infrastructure sharing, etc., can also been utilized through cooperatives or government.

\section{CONCLUSION}

Various resources have been identified for wastages of fruits and vegetable such as poor planning and forecasting demand, poor packing methodology, lack and unaware of cold storage, poor quality goods, stagnating goods due to unsold, poor transportation decisions, careless handling, increased number of distribution channels, lack of undertaking precaution methods etc. Out of all these factors, lack of cold storage is considered as primary reason for maximum wastage. Secondly more number of distribution channels is creating problem of more damage and price increase. Third major reason is that, unsold wastage. All other problems like poor packing, poor transport, poor quality of goods, lack of precaution methods, poor planning and forecasting leads to more unsold quantity of fruits and vegetables which creates value loss. Due to all the above reasons, total wastage from the retail outlets were estimated around $23 \%$. It means that, $23 \%$ of total investment on fruits and vegetable is simply getting waste due to wastage alone. Hence researcher suggested that, government or retail cooperatives can take measures as per discussions made in this research.

\section{REFERENCE}

[1] Indolink consulting's blog - Your business blog to India, Did you know that India is the largest producer of fruits and vegetables in the world?, June 15, 2011, Retrieved from http://indolinkenglish.wordpress.com/2011/06/15/

[2] Daily News \& Analysis (DNA), 72 percent of India's fruit, vegetable produce goes waste, Published: Monday, May 12, 2008, 18:14 IST, Agency: IANS Retrieved from http://www.dnaindia.com/india/report

[3] R. Arivazhagan and Ravilochanan, eproceedings for 2011, International research conference and colloquium, contemporary research issues and challenges in emerging economies, 2011

[4] D. D. Weatherspoon, J. F. Oehmke, M. Coleman, and L. Weatherspoon, "Price and Income Elasticities for Fresh Fruits and Vegetables in an Urban Food Desert," SSRN, March 16, 2011

[5] M. Fehr and D. C. Romão, "Modeling the success of fruit and vegetable marketing," International Journal of Postharvest Technology and Innovation, vol. 2, no.1, pp. 04 - 12, 2010.

[6] K. Weinberger, C. Genova II, and A. Acedo, "Quantifying postharvest loss in fruits and vegetables along the supply chain in Vietnam, Cambodia and Laos," International Journal of Postharvest Technology and Innovation, vol. 1, no.3, pp.288 - 297, 2008.

[7] R. C. Flemmer and C. L. Flemmer, "Innovations in fruit packing: a slow kiwifruit packing line and a robotic apple packer," International Journal of Postharvest Technology and Innovation, vol. 2, no. 2, pp.120 - 130, 2011.

[8] A. F. Bollen, "Technological innovations in sensors for assessment of postharvest mechanical handling systems," International Journal of Postharvest Technology and Innovation, vol. 1, no.1, pp.16 - 31, 2006.

[9] A. Veena, K. N. Babu, and H. R. Venkatesha, "Supply chain: a differentiator in marketing fresh produce," The IUP Journal of Supply Chain Management, vol. VIII, no. 1, pp. 23-36, March, 2011.

[10] Supply chain of fruits and vegetable, 2010, June 24, Articles Base SC \#2720238, Retrieved from www.articlesbase.com

[11] Ministry of food processing industries, 2007, Present Status and Future Prospects of Indian Food Processing Industries, Retrieved from http://mofpi.nic.in/ContentPage.aspx CategoryId=122

[12] K. Lakshmi, 2010, June, Low patronage for cold storage facility, The Hindu, Retrieved from http://www.hindu.com/2010/06/25/stories/2010062563200300.htm

[13] V. Basil Hans, Food Security and Sustainability in India, Social Science Research Network, January 22, 2011

[14] Mridula Velagapudi, Entrepreneurship - You have it in you, Retail industry in India: A Perspective, retrieved from http://www.entrepreneurswebsite.com/2011/02/09/

[15] Government of India, Ministry of food processing industries (2006 Nov) Eleventh five year plan, Report of the working group on food processing sector.

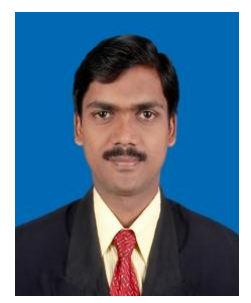

R. Arivazhagan, first author, has born on $29^{\text {th }}$ May 1980, at Dharmapuri, Tamilnadu, India. He is currently pursuing Ph.D in the field of Marketing of Indian Food Processing Industries especially in Fruits and Vegetables wastages since 2010. He has completed Bachelor of Technology in Food Process Engineering at Tamilnadu Agriculture University, Coimbatore, Tamilnadu, India during 1998 - 2002 and Master of Business Administration in the field of Marketing at Madurai Kamaraj University, Madurai, Tamilnadu, India during 2005 - 2007.

$\mathrm{He}$ is currently working as Assistant Professor in the School of Management, SRM University, Kattankulathur, Kanchipuram Dt, Tamilnadu, India. He was previously working in different organizations 
such as Assistant Manager for business developments in TA Labs Pvt Ltd, Chennai, Business Development Executive in AXIS Bank, Chennai, Project Executive in Mansys Consultancy Services, Chennai and Ancillary Units Incharge in Hindustan Unilever Ltd (Modern Foods Division), Chennai. He has published four articles in National level journals, eight articles in International level conference proceedings and nine articles in
National level conference proceedings. He is very keen to do researches in the field of Marketing of Indian Food Processing Industries.

Mr. R. Arivazhagan is a life member of both All India Management Association (AIMA) and Madras Management Association (MMA). Moreover he is life member of Indian Science congress Association. He is also in the member of ISSRN online journal portal and International Economics Development and Research Center (IEDRC). 